among other matter, gives extracts from the new German law controlling vivisection, which show that the German regulations governing experiments on living animals are substantially the same as those which have been enforced by the Home Secretary in Great Britain for more than half a century.

\section{National Baby Week Council}

The annual report of this Council, recently issued, describes the work accomplished during 1933 and constitutes another record of increased activity and influence. A tribute is paid to the co-operation of the Press and of shops and stores in propaganda respect. ing maternity and child welfare problems. It is suggested that propaganda should this year be devoted to the subject of "The Making of an A.1. Nation", and "National Baby Week" is to be celebrated on July 1-7. The Council has suffered from the financial stringency, but by exercising the strictest economy, income for the year exceeded expenditure by the small margin of about $£ 12$.

\section{South-Eastern Union of Scientific Societies}

The thirty-ninth Annual Congress of the SouthEastern Union of Scientific Societies will be held at the University of Reading on July 11-14, under the presidency of Prof. H. L. Hawkins, professor of geology in the University. On July 11, Prof. Hawkins will deliver his presidential address entitled "Fossils and Men". The presidents of sections will deliver the following addresses during the Congress: T. D. Kendrick (Archæology), "The Art and Archæology of the Early Anglo-Saxons"; Dr. Macgregor Skene (Botany), "Some Problems of Germination"; Dr. C. B. Williams (Zoology), "Insect Immigration in Great Britain"; T. H. Edmunds (Geology), "The Water Supply and Geology of the South-East of England; C. H. Grinling (Regional Survey), "Surrey for Action". On July 13, at 8 p.m., Prof. E. B. Poulton will deliver a public lecture entitled "The Power of Changing Colour as a Form of Protective Resemblance". Further information can be obtained from the Hon. General Secretary, 14, High View Close, Norwood, S.E.19.

\section{American Academy of Arts and Sciences}

At the annual meeting of the American Academy of Arts and Sciences held on May 9, the following officers were elected for 1934-35 : President, Prof. G. H. Parker ; Corresponding Secretary, Prof. Tenney L. Davis; Recording Secretary, W. E. Clark; Treasurer, I. Bowditch ; Librarian, Prof. Alfred C. Lane; Editor, Prof. Robert P. Bigelow; Foreign Honorary Members, Prof. R. A. Fisher, Galton professor of eugenics in University College, London ; Prof. A. V. Hill, Foulerton Research professor of the Royal Society, and University professor of physiology in University College, London; Prof. Arthur H. Holmes, professor of geology in the University of Durham; Prof. Paul Janet, professor of electrotechnics in the Sorbonne, Paris; Prof. Luigi Lombardi, Rome; and Prof. R. Willstätter, Munich.

\section{Announcements}

Prof. A. V. HIIL will open a discussion at the Royal Society on June 14 on "Methods of Measuring and Factors Determining the Speed of Chemical Reaction".

The Right Hon. Walter E. Elliot, Minister of Agriculture and Fisheries, will inspect the field plots and laboratories of the Rothamsted Experimental Station on June 20, at 11.15 a.m. On the same day, Mr. Elliot will present to the Trustees the deeds of the land newly acquired as a result of the recent public appeal.

Prof. J. B. Conant, president of Harvard University, formerly professor of chemistry in the University, has been awarded the medal of the American Institute of Chemists. The award is made in recognition of "outstanding service to the science of chemistry and the profession of chemists in America". Prof. Conant is well known for his work on reduction and oxidation in organic chemistry, and on hæmoglobin and chlorophyll.

WE have received the second supplement, 19311933, to the "Catalogue of Lewis's Medical and Scientific Lending Library" (London: Lewis's Library, 136, Gower Street, London, W.C.1. 2s. net). Works are listed alphabetically under authors' names, and at the end there is a classified index of subjects, under each of which authors' names are given, and the full title of the works will be found on reference to the body of the catalogue. All the sciences appear to be represented, and the list contains nearly 3,000 titles.

Applications are invited for the following appointments, on or before the dates mentioned :-An assistant lecturer in physics in King's College, London - The Secretary (June 12). A veterinary officer to the Berkshire County Council-The Clerk, Shire Hall, Reading (June 19). Assistant lecturers in geology and geography, chemistry, and physics at University College, Swansea-The Registrar (June 20). A superintendent of parks in the Borough of BarkingThe Town Clerk, Town Hall, Barking (June 20). A lecturer (woman) in geography at Norwich Training College-The Principal (June 20). An inspector of agriculture in the Department of Agriculture and Forests, Sudan Government-The Controller, Sudan Government London Office, Wellington House, Buckingham Gate, London, S.W.1 (June 21). A lecturer in pure and, applied technology at Leicester College of Technology-The Director of Education (June 22). An assistant in the Department of Natural Philosophy in the University of St. Andrews-The Secretary (June 23). A senior lecturer in mathematics at the Huguenot University College, Wellington, Cape Province, South Africa-The Registrar (Aug. 14). Evening teachers of pure and applied mathematics, economics, economic geography, etc., at the Wandsworth Technical Institute, London, S.W.18-The Secretary.

Erratum : Nature, June 2, p. 837. "Chemistry of Red and Brown Algæ." For "polymerised uronic acid" read "polymerised mannuronic acid". 